\title{
Spectroscopic Characterization and Gel Properties of Agar from Two Gelidium Species from the Atlantic Coast of Morocco
}

\author{
Zahira Belattmania ${ }^{1 * *(D)}$, Fouad Bentiss ${ }^{2,3}$ (D) , Charafeddine Jama ${ }^{3}$ (D) , Amal Nadri ${ }^{1}$, Abdeltif Reani ${ }^{1}$ (D), \\ Brahim Sabour 1 (D)
}

1 R.U. Phycology, Blue Biodiversity \& Biotechnology—P3B, Laboratory of Plant Biotechnology, Ecology and Ecosystem Valorization, Faculty of Sciences, Chouaïb Doukkali University, P.O. Box 20, El Jadida M-24000, Morocco; belattmania.z@ucd.ac.ma (Z.B.); Amal.Nadri.ucd@gmail.com (A.N.); abreani@yahoo.fr (A.R.); sabour.b@ucd.ac.ma (B.S.);

2 Laboratory of Catalysis and Corrosion of Materials, Faculty of Sciences, Chouaïb Doukkali University, P.O. Box 20, El Jadida M-24000, Morocco; fbentiss@gmail.com (F.B.);

3 University of Lille, CNRS, INRAE, Centrale Lille, UMR 8207, UMET-Unité Matériaux et Transformations, F-59000 Lille, France; charafeddine.jama@centralelille.fr (C.J.) ;

* Correspondence: belattmania.z@ucd.ac.ma (Z.B.)

Scopus Author ID 56676284700

Received: 29.12.2020; Revised: 23.01.2021; Accepted: 25.01.2021; Published: 31.01.2021

Abstract: The commercial value of agar in the phycocolloid market depends mostly on the agar yield and quality. The present study investigates the agar content and characterization of two Gelidiales Gelidium corneum and Gelidium microdon from the Moroccan Atlantic coast. Spectroscopic and rheological characterization of extracted agar without and with alkali pretreatments were evaluated. The highest agar yield was detected for mild alkaline pretreatment $\left(\mathrm{N}_{2} \mathrm{CO}_{3}\right)$. The native agar content in $G$. corneum was $16.21 \%$, while those pretreated with $\mathrm{NaOH}$ and $\mathrm{N}_{2} \mathrm{CO}_{3}$ ranged from 6.2 to $20.50 \%$. The agar yields of G. microdon showed values of $12.23 \%, 14.87 \%$, and $17.73 \%$, corresponding respectively to native agar, $\mathrm{NaOH}$, and $\mathrm{Na}_{2} \mathrm{CO}_{3}$ pretreatments. Agar with alkali pretreatments depicted the better gelling property with higher gel strength and elevated gelling and melting temperatures. ${ }^{13} \mathrm{C}$ NMR spectroscopy showed that G. Corneum has a typical unsubstituted and weakly methylated agar pattern. However, G. microdon revealed the presence of methyl and sulfate groups at the C4 of 4-O-L-galactose residues, responsible for the low gelling ability of the native agar. The decline of sulfate groups after alkali pretreatments were proved by FTIR spectroscopy. This study demonstrates that G. microdon produces a quality of agar similar to that of G. corneum. Thus G. microdon could be regarded as a potential additional source of agar industry in Morocco.

Keywords: agar; ${ }^{13} \mathrm{C}$ NMR; FT-IR; Florideophyceae; Morocco.

(C) 2021 by the authors. This article is an open-access article distributed under the terms and conditions of the Creative Commons Attribution (CC BY) license (https://creativecommons.org/licenses/by/4.0/).

\section{Introduction}

The seaweed hydrocolloids have attracted considerable interest in terms of their industrial commercialization [1-6]. The phycocolloids industry is incessantly rising at level of 2-3\% per year [7], with an annual global production that recently achieved 100,000 tons and a gross market value of above US\$ 1.1 billion [8]. According to Rhein-Knudsen et al. [9] and Veeragurunathan et al. [10], the agar gave the highest retail price per $\mathrm{kg}$ (18 US\$/kg) compared to the alginates with value of $12 \mathrm{US} \$ / \mathrm{kg}$ and carrageenans with $10.4 \mathrm{US} \$ / \mathrm{kg}$. 
Agar is a strongly gelling hydrocolloid that occurs in the cell-matrix of marine red algae. Its main structure is chemically characterized by repetitive units of $\beta$-D-galactose and 3,6-anhydro- $\alpha$-L-galactose [11-13]. Substitution with sulfates, methyl ethers, and/or pyruvate ketals can occur at various sites in the polysaccharide chain $[14,15]$. The agar is used as a gelling agent in many foods and industrial applications[16-18]. The use of agar in foods was widespread throughout the Far East, including Japan, China, Taiwan, Korea, the Philippines, and Indonesia [14].

The commercial value of agars is mainly linked to their yield and quality. Some Gelidium species are globally used to extract agars [14,17,19]. The natural stocks represent the significant source for the agar industry [20]. The demand for agar from Gelidium has currently exceeded the offer [21]. The bacteriological agar demand from Gelidium shifted from $250 \mathrm{~T}$ to about $700 \mathrm{~T}$ [20].

Morocco is the world's fifth-largest agar exporter, following Chile, China, Indonesia, and Spain [22]. Between 2012 and 2016, the annual export weight of agar in Morocco varied from 905 tonnes to 1066 tonnes, respectively [22]. The authorized export quota of locally produced agar is 1247 tonnes annually [23]. Gelidium corneum is the main species exploited for the local agar production. The available data and statistics on monitoring the Gelidium corneum population reported that this species is overexploited [24]. Furthermore, the number of Gelidium collectors without a harvest license was out of control. The collect season was often not respected. To ensure the continuity of seaweed production at the local scale, as an environmentally and economically sustainable activity, an intensive effort in fundamental research is required to consider other algal resources from the Moroccan coast with potential industrial interest. In this context, this study aims to evaluate the yield and the spectroscopic and rheological characterization of the agars, under different types of extraction, from Gelidium corneum and Gelidium microdon harvested from the Moroccan Atlantic coast.

\section{Materials and Methods}

\subsection{Sample collection.}

Samples of Gelidium corneum and Gelidium microdon were harvested in March 2020 on the rocky coast of Sidi Bouzid, El Jadida, Morocco (33 $13^{\circ} 55.8^{\prime \prime}$ N $8^{\circ} 33^{\prime} 24.8^{\prime \prime} \mathrm{W}$ ). The thalli were rinsed with tap water and distilled water to remove attached shells, sand, and other algae. Seaweed samples were sun-dried for 3 days and then dried in the oven at $50^{\circ} \mathrm{C}$ to constant dry weight.

\subsection{Agar extraction.}

Native agar extraction was done using dry algae $(10 \mathrm{~g})$ hydrated in $500 \mathrm{ml}$ distilled water at ambient temperature for $2 \mathrm{~h}$ and then heated at $100{ }^{\circ} \mathrm{C}$ for $1 \mathrm{~h}$. The mixture was filtered using a filter cloth. The filtrates were allowed to gel at room temperature, frozen overnight, and thawed. The thawed gel was then washed and dehydrated with ethanol (96\%) and was oven-dried $\left(50^{\circ} \mathrm{C}\right)$ to constant weight.

Alkali-pretreated agar extraction was performed according to two alkali pretreatment procedures: i) Alkaline pretreatment using $\mathrm{NaOH}$ according to the method described by Villanueva et al. [25], with modification. $10 \mathrm{~g}$ of dry algae soaked in $500 \mathrm{~mL}$ of $10 \% \mathrm{w} / \mathrm{v}$ $\mathrm{NaOH}$ solution and heated in a water bat at $90^{\circ} \mathrm{C}$ for $2 \mathrm{~h}$. The algal material was washed thoroughly with distilled water and then soaked in acetic acid $(0.5 \%)$ at room temperature for 
$1 \mathrm{~h}$. The Acetic acid solution was thrown, and seaweeds were extracted with $500 \mathrm{~mL}$ distilled water (with a $\mathrm{pH} 6.5$ ) at $100^{\circ} \mathrm{C}$ for $1 \mathrm{~h}$. The other remaining processes were done the same way as the native agar extraction. $\mathrm{ii}$ ) Alkaline pretreatment using $\mathrm{Na}_{2} \mathrm{CO}_{3}$ according to the method described by Freile-Pelegrin et al. [26] slightly modified. Before the extraction, $10 \mathrm{~g}$ of dried seaweeds were exposed to $0.5 \%$ solution of $\mathrm{Na}_{2} \mathrm{CO}_{3}(500 \mathrm{ml})$ at $90{ }^{\circ} \mathrm{C}$ for $30 \mathrm{~min}$ and then washed with distilled water 4 times. The agar was extracted with distilled water at $\mathrm{pH} 6.5$ and $100{ }^{\circ} \mathrm{C}$ for $2 \mathrm{~h}$.

\subsection{Spectroscopic characterization.}

\subsubsection{FT-IR.}

FTIR spectral measurements of the agars samples were performed using a Thermo Scientific Nicolet Impact 400D FT-IR Spectrometer (Nicolet Instrument Co., Madison USA). The spectra were scanned between 4000 and $500 \mathrm{~cm}^{-1}$ in attenuated total reflectance (ATR) mode. A total of 32 scans were averaged for each sample at a $4 \mathrm{~cm}^{-1}$ resolution, and subsequently, the IR spectra were processed using the OMNIC software (Nicolet, Madison, USA).

\subsection{2. ${ }^{13} \mathrm{C}$ NMR.}

The ${ }^{13} \mathrm{C}$ NMR spectroscopic measurements of agar samples dissolved in $\mathrm{D}_{2} \mathrm{O}$ were carried out at $353 \mathrm{~K}$ on Spectrometer AV II, operating at $400 \mathrm{MHz}$ equipped with pulsed gradient units, using a $5 \mathrm{~mm}$ Triple resonance Broadband Inverse probe at a base frequency of 100.62 MHz. Presaturation was applied during the relaxation delay and mixing time. The raw data were apodized in one dimension with 0.5 for line broadening prior to Fourier transformation.

\subsection{Rheological analyses.}

Solutions $(1.5 \% \mathrm{w} / \mathrm{v})$ of extracted and commercial agar (Bacteriological agar type E, Biokar diagnostics, A1012 HA) were prepared and allowed to gel overnight at room temperature. The Gel strength was evaluated by measuring the load $\left(\mathrm{g} / \mathrm{cm}^{2}\right)$, causing a cylindrical plunger $\left(1 \mathrm{~cm}^{2}\right.$ cross-section) to break the gel in the 20s [27]. Gelling and melting temperatures were determined according to the method described by Freile-Pelegrin and Robledo [28] with modification. $1.5 \%$ of extracted and commercial agar each separately were stirred for $5 \mathrm{~min}$ at $95^{\circ} \mathrm{C}$ in the water bath. The gelling temperature was measured by cooling $20 \mathrm{~mL}$ of hot agar solutions placed in test tubes (15 mm diameter, $200 \mathrm{~mm}$ height), including iron bead ( $8 \mathrm{~mm}$ diameter). The tubes were tilted up and down at room temperature until the bead ceased moving. The gel temperature was immediately measured by introducing a precision thermometer $\left(0.1^{\circ} \mathrm{C}\right.$ divisions $)$ into the agar. Melting temperature was measured on the same tubes used for the gelling temperature by clamping the tubes test in a water-bath. The temperature rose from 50 to $100^{\circ} \mathrm{C}$ at $0.5^{\circ} \mathrm{C} / \mathrm{min}$. The melting point was recorded with a precision thermometer when the bead sank into the solution. 


\section{Results and Discussion}

\subsection{Extraction yield.}

The agar yields from Gelidium species without and with alkali pretreatment are presented in Table 1. G. corneum showed agar yield varying from 6.20 to $20.50 \% \mathrm{dw}$, while G. microdon depicted agar contents from 12.23 to $17.73 \% \mathrm{dw}$. The assessment of these extraction yields with values previously recorded in the literature is very complex due to various factors such as collection time and region, environmental and physical factors of the species, and extraction conditions [29,30]. The results showed that the samples pretreated with a mild alkaline solution of $\mathrm{Na}_{2} \mathrm{CO}_{3}(0.5 \%)$ give a high agar yield compared to native extraction and strong alkali pretreatment using $10 \% \mathrm{NaOH}$. It has been reported that the alkali pretreatment results in significantly decreased extraction yields [28,31,32]. However, other literature reports highlighted that pre-extraction treatment using alkali or acid promotes a rise in agar yield compare to untreated samples [33,34]. The alkali pretreatment using $10 \% \mathrm{NaOH}$ prior to the hot water extraction may have been too harsh for the Gelidium species resulting marked decrease in the extraction yields. This could be explained by the fact that the agar undergoes degradation and diffuses towards the aqueous medium during the alkaline treatment, thus causing the extraction yield to decrease $[30,35]$. The alkali concentration, pretreatment time, and temperature need to be optimized to minimize agar losses and enhance the extraction yield. Future investigation should be performed to verify the optimum extraction parameters needed to maximize agar yield and properties from both studied Gelidium species.

Table 1. Agar yield of G. corneum and G. microdon without and with different alkali pretreatments.

\begin{tabular}{l|c|c|c}
\multicolumn{2}{c}{} & Agar yeild (\% Dw) & \\
\cline { 2 - 4 } \multicolumn{2}{c}{ Native Extraction } & Pretreatment NaOH 10\% & Pre-treatment Na2 $\mathbf{C O}_{3} \mathbf{0 . 5 \%}$ \\
\hline G.microdon & $16.21 \pm 0.42$ & $6.20 \pm 0.9$ & $20.50 \pm 0.37$ \\
\hline & $12.23 \pm 0.74$ & $14.87 \pm 1.69$ & $17.73 \pm 1.34$
\end{tabular}

\subsection{FTIR spectroscopy.}

The ATR-FTIR spectra (Figure 1) of the extracted agars were recorded to identify major compositional differences between species and the used extraction method. All analyzed samples presented the typical spectra of agar-like galactans (Figure 1). The most characteristic bands were located at the region $800-1400 \mathrm{~cm}^{-1}$, typically recognized as agarocolloid [36]. The small band located at $852 \mathrm{~cm}^{-1}$, detected for native and $\mathrm{Na}_{2} \mathrm{CO}_{3}$ pretreated agar from $G$. microdon (Figure 1b), could be related to the sulfate groups at the C-4 position in the D-galactose units [36-39]. This pic disappears in agar pretreated with $10 \% \mathrm{NaOH}$. The bands at $887 \mathrm{~cm}^{-1}$ correspond to the $\mathrm{C}-\mathrm{H}$ bending at the anomeric carbon in $\beta$ galactopyranosyl residues [30,38]. This is at $928 \mathrm{~cm}^{-1}$ assigned to the $\mathrm{C}-\mathrm{O}$ vibration of 3,6-anhydro-galactose residue $[39,40]$. The intensity of the characteristic band around $928 \mathrm{~cm}^{-1}$ was relatively higher after alkaline pretreatment using $\mathrm{NaOH}$. It has been reported that alkaline pretreatment could convert sulfate substitution to 3,6-anhydrogalactose [30,41]. An intense absorption region centered at $1030 \mathrm{~cm}^{-1}$ and a band at $1147 \mathrm{~cm}^{-1}$ could be assigned to $\mathrm{C}-\mathrm{O}$ and $\mathrm{C}-\mathrm{C}$ stretching vibrations of the pyranose ring common to all polysaccharides [38-40]. The bands detected at $1243 \mathrm{~cm}^{-1}$, and $1365 \mathrm{~cm}^{-1}$ are attributed to the ester sulfate groups antisymmetric stretching vibration [38-40,42]. The decrease in amplitude at $1250 \mathrm{~cm}^{-1}$ was detected after alkali pretreatments with $\mathrm{NaOH}$ and $\mathrm{Na}_{2} \mathrm{CO} 3$ (Figure 1a,b). It has been previously suggested that eliminating unstable sulfate was achieved upon alkaline pretreatment [41]. 


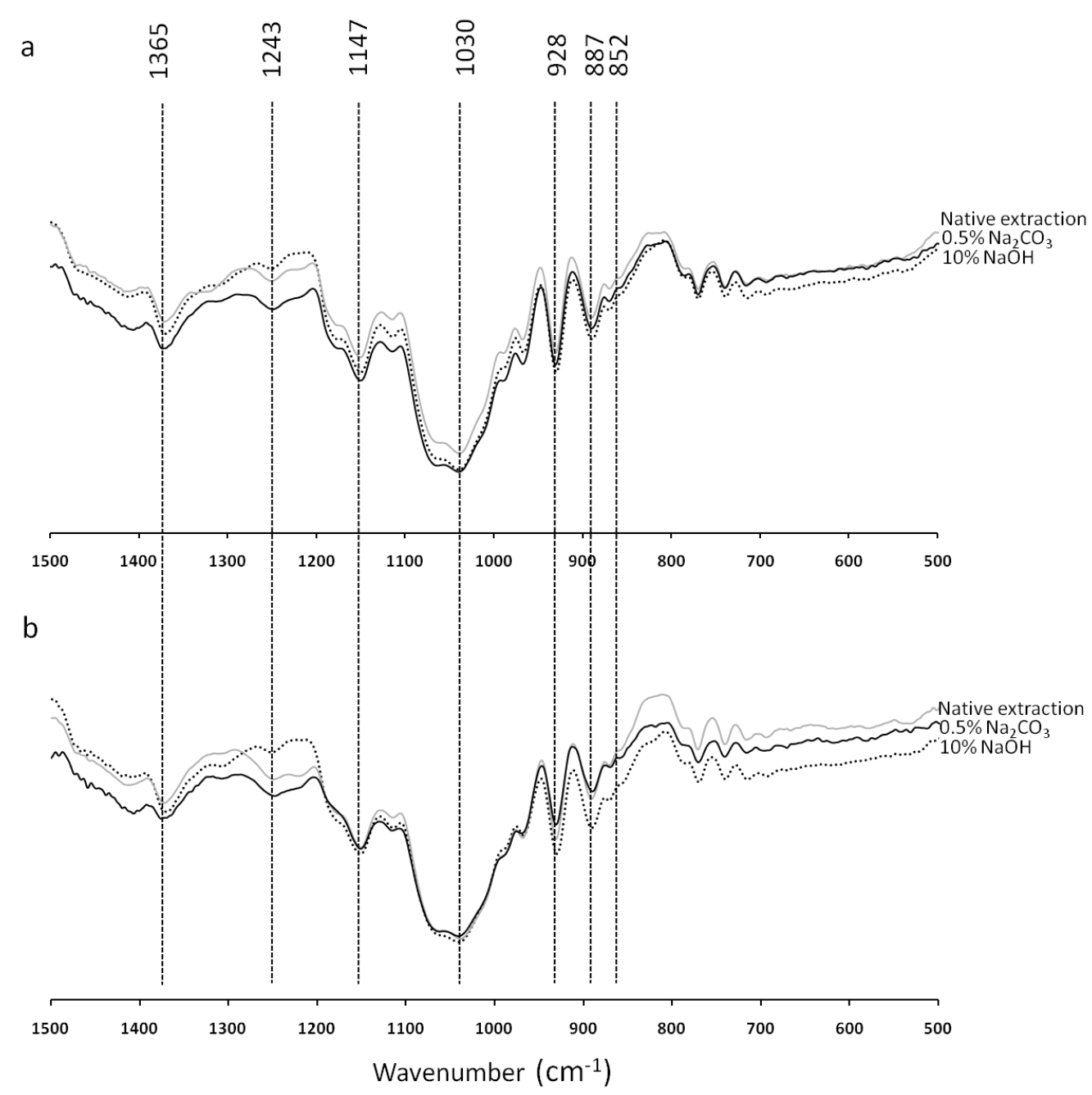

Figure 1. FTIR spectra of the agar extracted from (a) Gelidium corneum;(b) Gelidium microdon.

\subsection{NMR spectroscopy.}

Nuclear magnetic resonance (NMR) spectroscopy of ${ }^{13} \mathrm{C}$ is considered an efficient method to analyze red seaweed polysaccharides' structural features. The ${ }^{13} \mathrm{C}-\mathrm{NMR}$ spectra of native and alkali-treated samples (Figures 2 and 3) showed an agar-type structure with 12 signals attributed to the carbons in agarobiose. The ${ }^{13} \mathrm{C}-\mathrm{NMR}$ spectrum of the native agar from G. corneum (Figure 2a) was not significantly different from that shown in the alkali-treated agar (Figure 2b,c). All spectra in Figure 2 depicted signals at 102.6, 70.4, 82.4, 68.9, 75.5, and 61.6 ppm corresponding to $\mathrm{C} 1, \mathrm{C} 2, \mathrm{C} 3, \mathrm{C} 4, \mathrm{C} 5$, and $\mathrm{C} 6$ of $\beta$-D-galactopyranosyl 3-linked units [43], while the signals at 98.5, 80.3, 77.6, 75.8, 70.08, and $69.6 \mathrm{ppm}$ attributed to $\mathrm{C} 1, \mathrm{C} 3, \mathrm{C} 4$, C5 C6, and C2, respectively, in 3,6-anhydro 4-linked- $\alpha$-L-galactopyranosyl units [43-45]. The absence of the peak at $59.0 \mathrm{ppm}$ corresponding to the O-methyl group indicates a lowly methylated agarose structure $[44,46]$. Similarly, O-methyl groups have not been detected in the agar of G. corneum from on the northern coast of Spain [39]. Nevertheless, the native agar from G. microdon (Figure 3a) had a partially methylated agarose structure. It showed minor resonance at $59.4 \mathrm{ppm}$ typical of O-methylated agarobiose and another one at $98.9 \mathrm{ppm}$ imputed to agarobiose containing 2-O-methyl-3,6-anhydro-L-galactose $[43,46]$. 


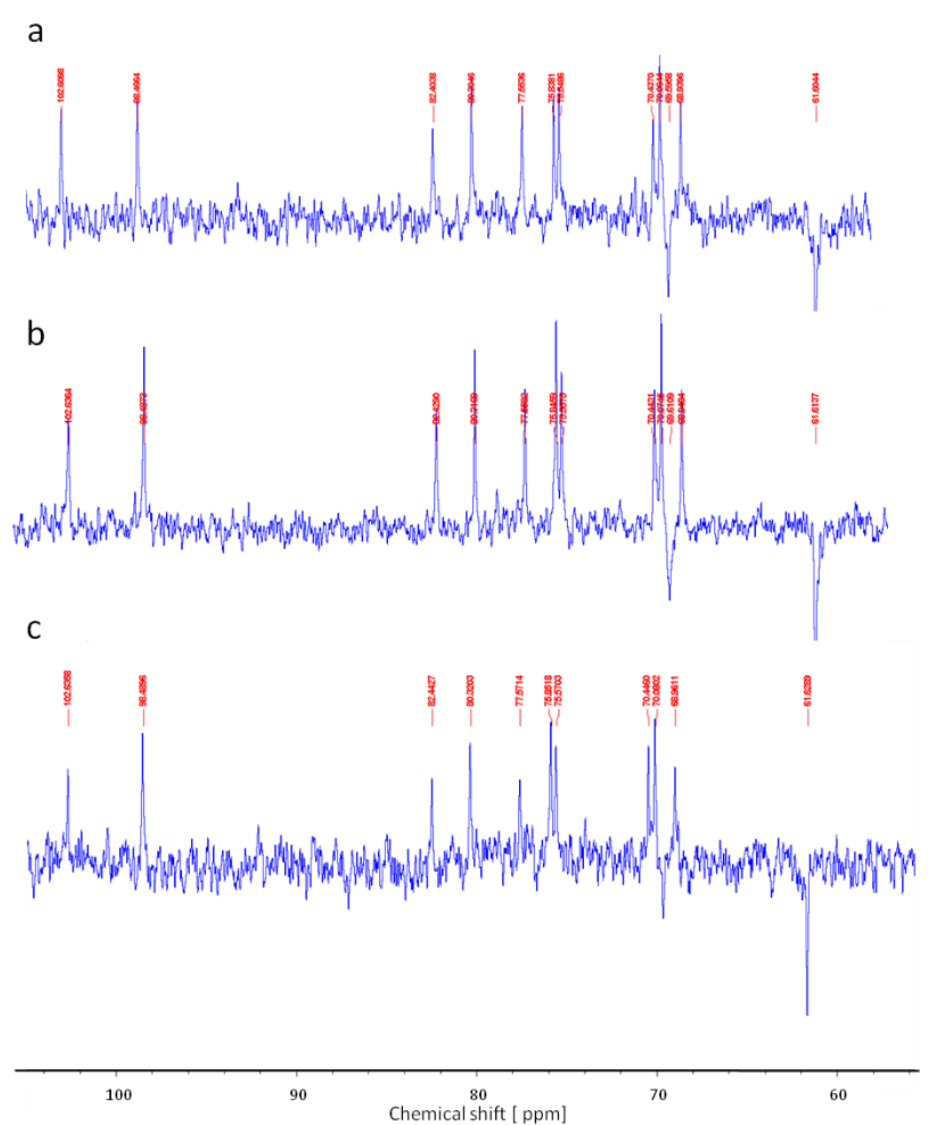

Figure 2. ${ }^{13} \mathrm{C}$ NMR spectra of agar extracted from Gelidium corneum; (a) native agar; (b) agar pretreated with $10 \% \mathrm{NaOH} ;(\mathbf{c})$ agar pretreated with $0.5 \% \mathrm{Na}_{2} \mathrm{CO}_{3}$.

a

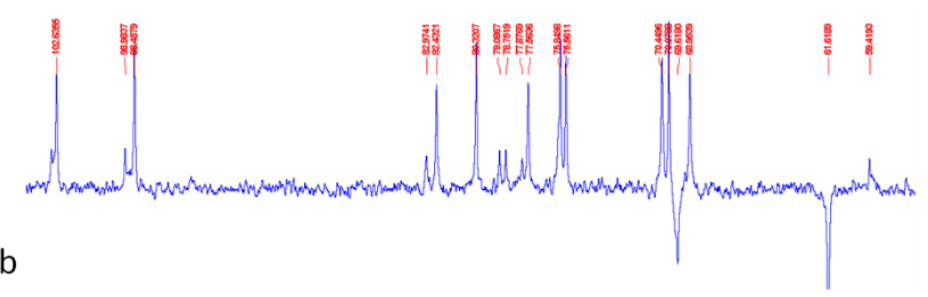

b
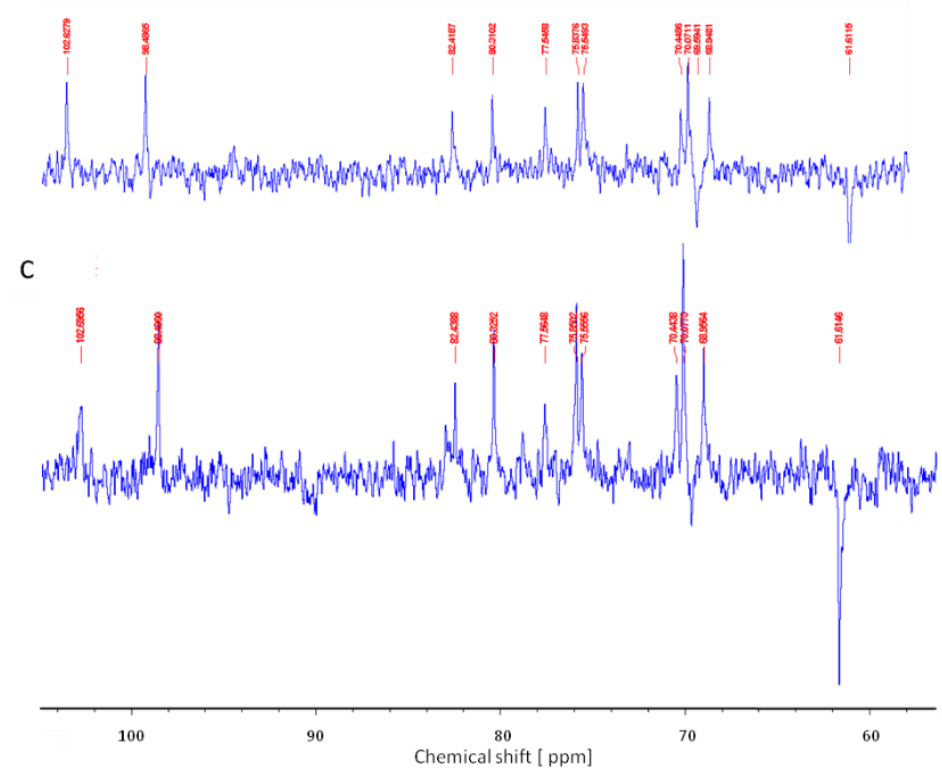

Figure 3. ${ }^{13} \mathrm{C}$ NMR spectra of agar extracted from Gelidium microdon; (a) native agar; (b) agar pretreated with $10 \% \mathrm{NaOH} ;(\mathbf{c})$ agar pretreated with $0.5 \% \mathrm{Na}_{2} \mathrm{CO}_{3}$. 
The comparison of the ${ }^{13} \mathrm{C}$-NMR spectrum of native Agar from G. microdon (Figure 3a) and those of agar obtained after alkali pretreatment (Figure 3b,c) showed the disappearance of the signal at $78.7 \mathrm{ppm}$ attributed to $\mathrm{C} 4$ in 4-O-L-galactose-6-sulfate $[43,47]$.

\subsection{Rheological properties.}

\subsubsection{Gel strength.}

Gel strength is the main indicator of agar quality. It refers to the compressive force required to fracture an agar gel of a standard concentration of $1.5 \%(\mathrm{w} / \mathrm{v})$. G. corneum showed higher gel strength than G. microdon (Table 2). The maximum value was detected for alkali treatment $10 \% \mathrm{NaOH}$ with $528.55 \pm 11.08 \mathrm{~g} . \mathrm{cm}^{-2}$ and $489.00 \pm 19.41 \mathrm{~g} . \mathrm{cm}^{-2}$ in $G$. corneum and G. microdon, respectively. Alkali treatment's ability to reduce the sulfate content and improve the gel strength of agars has already been demonstrated for Gelidium species [35,48,49]. Fundamentally, agar gelation arises during the aggregation of helical conformation of agar polymers via hydrogen bonds. The charged groups (sulfate group) interfered with the intermolecular hydrogen bonding for double helices formation [50]. Thus, the decline of the sulfate group by alkaline hydrolysis contributes to increasing the ability to form double helices, strengthening the gel network [51]. The gels obtained from the commercial agar presented greater fracture strength values (Table 2). Nevertheless, the agars from both Gelidium species showed gel strength values within the range required by the international market. The latter, commonly, agree to the standard values appointed by the Japanese Specifications for Processed Agar (JSPA), which is $350 \mathrm{~g} . \mathrm{cm}^{-2}$ for $1.5 \%$ (w/v) of the first-grade agar and $600 \mathrm{~g} . \mathrm{cm}^{-2}$ for the higher grade agar, as measured by the Nikan-Sui method [52,53].

Table 2. Gel strength of agar from G. corneum and G. microdon without and with different alkali pretreatments.

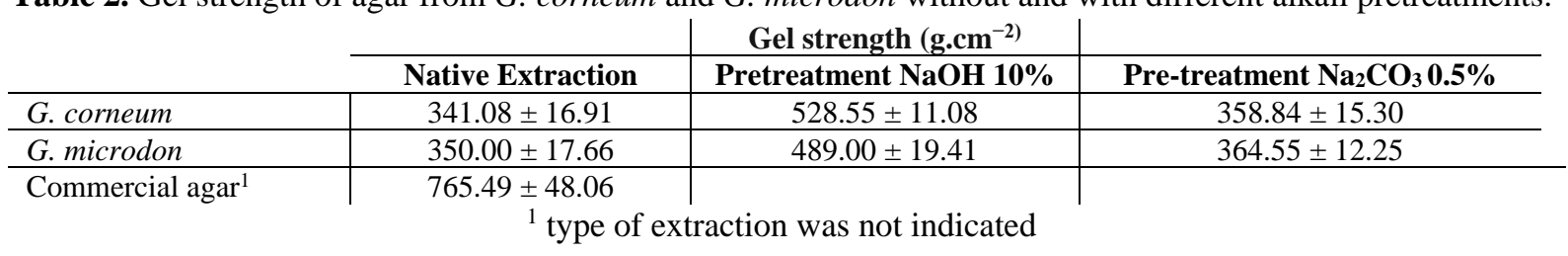

3.4.2. Gelling and melting temperatures.

Gelling and melting temperatures of agars without and with different alkaline pretreatments are presented in Table 3. Commercial agar had melting and gelling temperatures of 82.1 and $32.8^{\circ} \mathrm{C}$, respectively. The G. corneum's Gelling temperature ranged from 36 to $39^{\circ} \mathrm{C}$, while G. microdon showed a gelling temperature of $35-38^{\circ} \mathrm{C}$. These findings seem to corroborate the established negative relationship between methoxyl and sulfate contents and the gelling temperature [54,55]. As ${ }^{13} \mathrm{C}$ NMR highlighted, G. microdon spectra indicated a partially methylated agarose structure with the presence of sulfate groups in native agar. This could partially explain the lower gelling temperature recorded in G. microdon compared to $G$. corneum. The difference in gelling temperature between species may also be due to molecular weight, and molecular weight distribution may have an essential role in agar's gelation process [56]. Generally, Gelidium species have gelling temperatures in the range of $34-39^{\circ} \mathrm{C}$ [26,57]. It is evident that the extraction processes influenced both gelling and melting temperatures. The native agar formed gel at $35.12-36.01^{\circ} \mathrm{C}$, and those with $\mathrm{N}_{2} \mathrm{CO}_{3}$ pretreatment became gel at a temperature range of $36.25-37.25^{\circ} \mathrm{C}$, while agar with $\mathrm{NaOH}$ pretreatment formed gel at $38.27-39.16^{\circ} \mathrm{C}$. The corresponding gels molt at $85.65-86.71^{\circ} \mathrm{C}, 86.32-87.13^{\circ} \mathrm{C}$, and $88.31-$ 
$89.83^{\circ} \mathrm{C}$, respectively. Higher melting temperatures of agar gels with alkaline pretreatment revealed that they were more stable than those of native agar [41]. It has been reported that pretreatment using $\mathrm{NaOH}$ concentration than $4 \%$ resulted in increases in gelling and melting temperatures [25].

Table 3. Gelling and melting temperatures of agar from G. corneum and G. microdon without and with different alkali pretreatments.

\begin{tabular}{|c|c|c|c|}
\hline & & Melting temperature $\left({ }^{\circ} \mathbf{C}\right)$ & Gelling temperature $\left({ }^{\circ} \mathbf{C}\right)$ \\
\hline \multirow[t]{3}{*}{ Gelidium corneum } & Native Extraction & $86.7 \pm 0.6$ & $36.0 \pm 0.9$ \\
\hline & $\mathrm{Na}_{2} \mathrm{CO}_{3} 0.5 \%$ & $87.1 \pm 0.6$ & $37.2 \pm 0.9$ \\
\hline & $\mathrm{NaOH} 10 \%$ & $89.8 \pm 0.1$ & $39.2 \pm 1.0$ \\
\hline \multirow{3}{*}{ Gelidium microdon } & Native Extraction & $85.6 \pm 0.2$ & $35.1 \pm 0.7$ \\
\hline & $\mathrm{Na}_{2} \mathrm{CO}_{3} 0.5 \%$ & $86.3 \pm 0.1$ & $36.2 \pm 0.5$ \\
\hline & $\mathrm{NaOH} 10 \%$ & $88.3 \pm 0.7$ & $38.3 \pm 0.8$ \\
\hline Commercial agar $^{1}$ & & $82.1 \pm 0.4$ & $32.8 \pm 0.3$ \\
\hline
\end{tabular}

\section{Conclusions}

Spectroscopic and rheological characterization of agar extracted from the Moroccan Gelidiales G. corneum and G. microdon without and with alkali pretreatments $(\mathrm{NaOH}$ and $\mathrm{N}_{2} \mathrm{CO}_{3}$ ) were investigated. The highest agar yields (17.73-20.5\%) of both species were obtained from mild alkaline pretreatment using $0.5 \% \mathrm{~N}_{2} \mathrm{CO}_{3}$. The native agar of G. corneum and G. microdon does not exceed $16.21 \%$ and $12.23 \%$, respectively. The alkali pretreatments improved the gel strength, gelling, and melting temperatures. ${ }^{13} \mathrm{C}$ NMR spectra of $G$. Corneum demonstrated the characteristic pattern of unsubstituted and lowly methylated agar. Though, the native extraction of G. microdon gave agar substituted with methyl and sulfate groups at the $\mathrm{C} 4$ of 4-O-L-galactose residues, responsible for the low gelling ability of native agar. The FTIR spectroscopy revealed that both Gelidium species presented the typical spectra of agarlike galactans, attenuating sulfate groups after alkali pretreatment. G. microdon produces a quality of agar after alkaline treatment comparable to that of G. Corneum. Thus, G. microdon could be regarded as a potential additional source of agar industry in Morocco. Future investigation should verify the optimum extraction parameters needed to maximize the agar yield and properties considering each species' life cycle and the seasonal variation in agar yield.

\section{Funding}

This research received no external funding.

\section{Acknowledgments}

This research has no acknowledgment.

\section{Conflicts of Interest}

The authors declare no conflict of interest.

\section{References}

1. Álvarez-Viñas, M.; Flórez-Fernández, N.; Torres, M.D.; Domínguez, H. Successful Approaches for a Red Seaweed Biorefinery. Mar. Drugs 2019, 17, 620,https://doi.org/10.3390/md17110620.

2. Pereira, L. Colloid Producing Seaweeds: Agarophytes, Carrageenophytes and Alginophytes Biodiversity. Encyclopedia of Marine Biotechnology 2020, 1, 161-326,https://doi.org/10.1002/9781119143802.ch8. 
3. Xiao, Q.; Weng, H.; Ni, H.; Hong, Q.; Lin, K.; Xiao, A. Physicochemical and gel properties of agar extracted by enzyme and enzyme-assisted methods. Food Hydrocolloids 2019, 87, 530540,https://doi.org/10.1016/j.foodhyd.2018.08.041.

4. Häder, D.-P. Chapter 9 - Phycocolloids from macroalgae. In Natural Bioactive Compounds, Sinha, R.p., Häder, D.-P., Eds. Academic Press: 2021; 187-201,https://doi.org/10.1016/B978-0-12-820655-3.00009-4.

5. Haroun, R.; Gil-Rodríguez, M.C.; Neto, A.I.; Machín-Sánchez, M.; Viera-Rodríguez, M.A. A review of current uses and potential biotechnological applications of seaweeds from the Macaronesian region (CentralEast Atlantic Ocean). J. Appl. Phycol. 2019, 31, 3777-3790,https://doi.org/10.1007/s10811-019-01889-4.

6. D'Armas, H.; Jaramillo, C.; D'Armas, M.; Echavarría, A.; Valverde, P. Proximate composition of several green, brown and red seaweeds from the coast of Ecuador. Rev. Biol. Trop. 2019, 67,http://dx.doi.org/10.15517/rbt.v67i1.33380.

7. Sahu, S.K.; Mantri, V.A.; Zheng, P.; Yao, N. Algae Biotechnology: Current Status, Potential and Impediments. Encyclopedia of Marine Biotechnology 2020, 1, 1-31,https://doi.org/10.1002/9781119143802.

8. Chew, K.W.; Juan, J.C.; Phang, S.M.; Ling, T.C.; Show, P.L. An overview on the development of conventional and alternative extractive methods for the purification of agarose from seaweed. Sep. Sci. Technol. 2018, 53, 467-480,https://doi.org/10.1080/01496395.2017.1394881.

9. Rhein-Knudsen, N.; Ale, M.T.; Meyer, A.S. Seaweed hydrocolloid production: an update on enzyme assisted extraction and modification technologies. Mar. Drugs 2015, 13, 33403359, https://doi.org/10.3390/md13063340.

10. Veeragurunathan, V.; Prasad, K.; Malar Vizhi, J.; Singh, N.; Meena, R.; Mantri, V.A. Gracilaria debilis cultivation, agar characterization and economics: bringing new species in the ambit of commercial farming in India. J. Appl. Phycol. 2019, 31, 2609-2621,https://doi.org/10.1007/s10811-019-01775-z.

11. Cotas, J.; Leandro, A.; Pacheco, D.; Gonçalves, A.M.M.; Pereira, L. A Comprehensive Review of the Nutraceutical and Therapeutic Applications of Red Seaweeds (Rhodophyta). Life 2020, 10, 19,https://doi.org/10.3390/life10030019.

12. Zhu, B.; Ni, F.; Xiong, Q.; Yao, Z. Marine oligosaccharides originated from seaweeds: Source, preparation, structure, physiological activity and applications, Crit. Rev. Food Sci. Nutr. 2020, 61, 6074,https://doi.org/10.1080/10408398.2020.1716207.

13. Rodríguez Sánchez, R.A.; Canelón, D.J.; Cosenza, V.A.; Fissore, E.N.; Gerschenson, L.N.; Matulewicz, M.C.; Ciancia, M. Gracilariopsis hommersandii, a red seaweed, source of agar and sulfated polysaccharides with unusual structures.Carbohyd Polym. 2019, 213, 138-146,https://doi.org/10.1016/j.carbpol.2019.02.071.

14. Hernández-Carmona, G.; Freile-Pelegrín, Y.; Hernández-Garibay, E. 14 - Conventional and alternative technologies for the extraction of algal polysaccharides. In Functional Ingredients from Algae for Foods and Nutraceuticals, Domínguez, H., Ed. Woodhead Publishing: 2013; 475516,https://doi.org/10.1533/9780857098689.3.475.

15. Rocha, C.M.R.; Sousa, A.M.M.; Kim, J.K.; Magalhães, J.M.C.S.; Yarish, C.; do Pilar Gonçalves, M. Characterization of agar from Gracilaria tikvahiae cultivated for nutrient bioextraction in open water farms. Food Hydrocoll. 2019, 89, 260-271,https://doi.org/10.1016/j.foodhyd.2018.10.048.

16. Din, S.S.; Chew, K.W.; Chang, Y.K.; Show, P.L.; Phang, S.M.; Juan, J.C. Extraction of agar from Eucheuma cottonii and Gelidium amansii seaweeds with sonication pretreatment using autoclaving method. J. Ocean. Limnol.2019, 37, 871-880,https://doi.org/10.1007/s00343-019-8145-6.

17. Martínez-Sanz, M., Martínez-Abad, A.; López-Rubio, A. Cost-efficient bio-based food packaging films from unpurified agar-based extracts. Food Packag. Shelf Life 2019, 21, 100367,https://doi.org/10.1016/j.fpsl.2019.100367.

18. Martínez-Sanz M.; Ström, A.; Lopez-Sanchez, P.; Knutsen, S.H.; Ballance, S.; Zobel, H.K.; Sokolova, A.; Gilbert, E.P.; López-Rubio, A. Advanced structural characterisation of agar-based hydrogels: Rheological and small angle scattering studies. Carbohydr Polym. 2020, 236, 115655,https://doi.org/10.1016/j.carbpol.2019.115655.

19. Mostafavi, F.S.; Zaeim, D. Agar-based edible films for food packaging applications - A review. Int. J. Biol. Macromol. 2020, 159, 1165-1176,https://doi.org/10.1016/j.ijbiomac.2020.05.123.

20. Santos, R.; Melo, R.A. Global shortage of technical agars: back to basics (resource management). J. Appl. Phycol. 2018, 30, 2463-2473, https://doi.org/10.1007/s10811-018-1425-2.

21. Callaway, E. Lab staple agar runs low: dwindling seaweed harvest imperils reagent essential for culturing microbes. Nature 2015, 528, 171-173,https://doi.org/10.1038/528171a.

22. Fao. The global status of seaweed production, trade and utilization. Globefish Research Programme Volume 124 2018, 120.

23. DGC. Direction Générale du Commerce (DGC)- Ministre de l'Industrie, du Commerce, de l'Investissement et de l'Economie Numérique. 2019. Avis no 16/19 aux exportateurs des algues brutes et d'agar agar. http://www.mcinet.gov.ma/ce/exportateurs/DocExport/avis_16-19.pdf.

24. Givernaud, T.; Sqali, N.; Barbaroux, O.; Orbi, A.; Semmaoui, Y.; Rezzoum, N.E.; Mouradi, A.; Kaas, R. Mapping and biomass estimation for a harvested population of Gelidium sesquipedale (Rhodophyta, Gelidiales) along the Atlantic coast of Morocco. Phycologia 2005, 44, 66-71, https://doi.org/10.2216/00318884(2005)44[66:MABEFA]2.0.CO;2. 
25. Villanueva, R.D.; Sousa, A.M.M.; Gonçalves, M.P.; Nilsson, M.; Hilliou, L. Production and properties of agar from the invasive marine alga, Gracilaria vermiculophylla (Gracilariales, Rhodophyta). J. Appl. Phycol. 2010, 22, 211-220,https://doi.org/10.1007/s10811-009-9444-7.

26. Freile- Pelegrin, Y., Robledo, D.R.; Garcfa-Reina, G. Seasonal agar yield and quality in Gelidium canariensis (Grunow) Seoane-Camba (Gelidiales, Rhodophyta) from Gran Canaria, Spain. Appl. Phycol.1995, 7, 141144,https://doi.org/10.1007/BF00693060.

27. Armisen, R.; Galatas, F. Production, properties and uses of agar. Production and utilization of products from commercial seaweeds. FAO Fish. Tech. Pap 1987, 288, 1-57.

28. Freile- Pelegrin, Y., Robledo, D.R. Influence of alkali treatment on agar from Gracilaria cornea from Yucatan, Mexico. J. Appl. Phycol.1997,9, 533-539,https://doi.org/10.1023/A:1007989931915.

29. Buriyo, A.S.; Kivaisi, A.K. Standing stock, agar yield and properties of Gracilaria salicornia harvested along the Tanzanian Coast. West. Indian Ocean J. Mar. Sci. 2003, 2, 171178,https://doi.org/10.4314/wiojms.v2i2.28433.

30. Martinez-Sanz, M., Gomez-Mascaraque, L.G.; Ballester, A.R.; Martinez-Abad, A.; Brodkorb, A.; LopezRubio A. Production of unpurified agar-based extracts from red seaweed Gelidium sesquipedale by means of simplified extraction protocols. Algal Res. 2019, 38, 101420,https://doi.org/10.1016/j.algal.2019.101420.

31. Arvizu-Higuera, D.L.; Rodríguez-Montesinos, Y.E.; Murillo-Álvarez, J.I.; Muñoz-Ochoa, M.; HernándezCarmona, G. Effect of alkali treatment time and extraction time on agar from Gracilaria vermiculophylla. $J$. Appl. Phycol. 2008, 20, 515-519,https://doi.org/10.1007/s10811-007-9258-4.

32. Kumar, V.; Fotedar, R. Agar extraction process for Gracilaria cliftonii, Carbohydr. Polym.2009, 78, 813819,https://doi.org/10.1016/j.carbpol.2009.07.001.

33. Ganesan, M.; Rao, P.S.V. Influence of post-harvest treatment on shelf life and agar quality in seaweeds Gracilaria edulis (Rhodophyta/Gigartinals) and Gelidiella acerosa (Rhodophyta/Gelidiales). Indian J. Mar. Sci. 2004, 33, 269-75.

34. Vuai, S.A.H.; Mpatani, F. Optimization of agar extraction from local seaweed species, Gracilariasalicornia in Tanzania. Phycological Res.2019, 67, 261-266,https://doi.org/10.1111/pre.12380.

35. Lemus, A.; Bird, K.; Kapraun, D.F.; Koehn, F. Agar yield, quality and standing crop biomass of Gelidium serrulatum, Gelidium floridanum and Pterocladia capillacea in Venezuela. Food Hydrocoll.1991, 5, 469479,https://doi.org/10.1016/S0268-005X(09)80105-7.

36. Melo, M.R.S.; Feitosa, J.P.A.; Freitas, A.L.P.; de Paula, R.C.M. Isolation and characterization of soluble sulfated polysaccharide from the red seaweed Gracilaria cornea. Carbohydr. Polym. 2002, 49, 491498,https://doi.org/10.1016/S0144-8617(02)00006-1.

37. Prado-Fernandez, J.; Rodriguez-Vazquez, J.A.; Tojo, E.; Andrade, J.M. Quantitation of $\kappa-$, 1- and $\lambda$-carrageenans by mid-infrared spectroscopy and PLS regression, Anal. Chim. Acta2003, 480, 2337,https://doi.org/10.1016/S0003-2670(02)01592-1.

38. Gómez-Ordónez, E.; Rupérez, P. FTIR-ATR spectroscopy as a tool for polysaccharide identification in edible brown and red seaweeds. Food Hydrocoll. 2011, 25, 15141520,https://doi.org/10.1016/j.foodhyd.2011.02.009.

39. Guerrero, P.; Etxabide, A.; Leceta, I.; Penalba, M.; de la Caba K. 2014.Extraction of agar from Gelidium sesquipedale (Rodhopyta) and surface characterization of agar based films.Carbohyd. Polym.2014, 99, 491498,https://doi.org/10.1016/j.carbpol.2013.08.049.

40. Sousa, A. M. M.; Morais, S.; Abreu, M. H.; Pereira, R., Sousa-Pinto, I.; Cabrita, E. J.; Delerue-Matos, C.; Gonçalves M.P. Structural, physical, and chemical modifications induced by microwave heating on native agar-like galactans. J. Agric. Food Chem.2012, 60, 4977-4985,https://doi.org/10.1021/jf2053542.

41. Yarnpakdee, S.; Benjakul, S.; Kingwascharapong, P. Physico-chemical and gel properties of agar from Gracilaria tenuistipitata from the lake of Songkhla, Thailand. Food Hydrocoll. 2015, 51, 217226,https://doi.org/10.1016/j.foodhyd.2015.05.004.

42. Chopin, T.; Kerin, B.; Mazerolle, R. Phycocolloid chemistry as a taxonomic indicator of phylogeny in the Gigartinales, Rhodophyceae: A review and current developments using Fourier transform infrared diffuse reflectance spectroscopy. Phycol. Res. 2006, 47, 167-188, https://doi.org/10.1046/j.1440-1835.1999.00170.x.

43. Lahaye, M.; Rochas C.; Yaphe, W. A new procedure for determining the heterogeneity of agar polymers in the cell walls of Gracilaria spp. (Gracilariaceae, Rhodophyta). Can J. Bot.1986, 64, 579585,https://doi.org/10.1139/b86-074.

44. Lahaye, M.; Yaphe, W.; Viet, M.T.P.; Rochas, C. 13C-n.m.r. spectroscopic investigation of methylated and charged agarose oligosaccharides and polysaccharides. Carbohydr. Res. 1989, 190, 249265,https://doi.org/10.1016/0008-6215(89)84129-1.

45. Falshaw, R.; Furneaux, R.H.; Pickering, T.D.; Stevenson, D.E. Agars from Three Fijian Gracilaria Species. Bot. Mar.1999, 42, 51-59,https://doi.org/10.1515/BOT.1999.008.

46. Murano, E.; Toffanin, R.; Zanetti, F.; Knutsen, S.H.; Paoletti, S.; Rizzo, R. Chemical and macromolecular characterisation of agar polymers from Gracilaria dura (C. Agardh) J. Agardh (Gracilariaceae, Rhodophyta), Carbohydr. Polym.1992, 18, 171-178,https://doi.org/10.1016/0144-8617(92)90061-T.

47. Freile-Pelegin, Y.; Murano, E. Agars from three species of Gracilaria (Rhodophyta) from Yucatan Peninsula. Bioresour. Technol.2005, 96, 295-302,https://doi.org/10.1016/j.biortech.2004.04.010. 
48. Matsuhiro, B.; Urzda, C.C. Agars from Gelidium rex (Gelidiales, Rhodophyta). In: Thirteenth International Seaweed Symposium, Vancouver, Canada, August 13-18, 1989, Developments in Hydrobiology; Lindstrom, S.C.; Gabrielson, P.W.; Eds.; Springer: Dordrecht, Netherlands, 1990; 545-549,https://doi.org/10.1007/97894-009-2049-1_78.

49. Meena, R.; Prasad, K.; Siddhanta, A.K. Preparation of superior quality products from two Indian agarophytes. J. Appl. Phycol.2011, 23, 183-189,https://doi.org/10.1007/s10811-010-9523-9.

50. Lahaye, M.; Rochas, C. Chemical structure and physico-chemical properties of agar. Hydrobiologia1991, 221, 137-148,https://doi.org/10.1007/BF00028370.

51. Rees, D.A. Shapely polysaccharides. The eighth Colworth Medal Lecture. Biochem. J. 1972, 126, 257 273,https://doi.org/10.1042/bj1260257.

52. Skriptsova, A.V.; Nabivailo, Y.V. Comparison of three gracilarioids: growth rate, agar content and quality. J. Appl. Phycol. 2009, 21, 443-450,https://doi.org/10.1007/s10811-008-9389-2.

53. Lee, W.K.; Lim, Y.Y.; Leow, A.T.C.; Namasivayam, P.; Ong Abdullah, J.; Ho, C.L. Factors affecting yield and gelling properties of agar. J. Appl. Phycol. 2017, 29, 1527-1540,https://doi.org/10.1007/s10811-0161009-y.

54. Guiseley, K.B. The relationship between methoxyl content and gelling temperature of agarose. Carbohydr. Res.1970,13, 247-256,https://doi.org/10.1016/S0008-6215(00)80831-9.

55. Andriamanantoanina, H.; Chambat, G.; Rinaudo, M. Fractionation of extracted Madagascan Gracilaria corticata polysaccharides: structure and properties. Carbohyd. Polym. 2007, 68, 7788,https://doi.org/10.1016/j.carbpol.2006.07.023.

56. Murano, E. Chemical structure and quality of agars from Gracilaria. J. Appl. Phycol.1995,7, 245254,https://doi.org/10.1007/BF00003999.

57. Guiseley, K.B. Chemical and physical properties of algal polysaccharides used for cell immobilization. Enzyme microb. Technol.1989, 11, 706-716,https://doi.org/10.1016/0141-0229(89)90119-1. 